\title{
Quantitative Morphologic Investigations on Ultrastructural Dynamics in Prolactin Cells of Mouse Anterior Pituitary during the Estrous Cycle, with Special Reference to the Mode of Granule-Release
}

\author{
By \\ Yoshie IWAMA and Masao SANO \\ Department of Anatomy, Nagoya University School of Medicine, \\ Tsurumaicho, Nagoya, 466, Japan \\ - Received for Publication, September 17, 1985-
}

\begin{abstract}
Key Words: Exocy tosis, Parenchymal basal lamina, Morphometry, Prolactin cell, Mouse.
Summary: Ultrastructural changes in prolactin cells of the mouse anterior pituitary gland during the estrous cycle were investigated using a morphometric method with the electron microscope. The secretory granules are released by exocytosis and the exocy totic figures showed a large fluctuation in number during the estrous cycle, being adundant in proestrus and estrus, scarce in metestrus and diestrus in a ration of $75: 7.5: 1: 2$, respectively. The length of the cell perimeter varied in a similar fashion. The volumes of cytoplasm, nucleus and cellorganelles also showed a similar variation throughout the estrous cycle, generally reaching the maximal level in proestrus and/or estrus, being smallest in metestrus and beginning to rise in diestrus. On the other hand, the frequency of exocy totic figures being open to the parenchymal basal lamina which delineated the pericapillary space were three- to five-fold over that of exocy totic figures being open to the in tercellular space through every days of the estrous cycle. This suggests that an interaction between the cell membrane and the parenchymal basal lamina may play an important role in the mechanism of exocytosis.
\end{abstract}

In the previous electron microscopic studies, the function which cell-organelles fulfil in the process of the prolactin synthesis and release in prolactin cells has been established in mice (Sano, 1962) and rats (Farquhar and Wellings, 1957; Smith and Farquhar, 1966; Farquhar, 1971; Farquhar et al., 1978). During the estrous cycle, clear cyclic fluctuations were observed in ultrastructure of prolactin cells (Sano, 1962; Sasaki, 1974; Pool et al., 1980a, $1980 \mathrm{~b}$ ), also in prolactin levels in the pituitary and serum (Kwa and Verhafstad, 1967; Sar and Meites, 1967; Niswender et al., 1969; Amenomori et al., 1970; Neill, 1970, 1972; Gay et al., 1970; Yanai and
Nagasawa, 1974; Wogensen and Warberg, 1984). However, a quantitative study on ultrastructural changes in prolactin cells has been scarcely ever undertaken (Poole et al., 1980a, 1980b). It is supported that the secretory granules in prolactin cells are discharged by a process termed exocytosis (Ichikawa, 1959; Sano, 1962; Smith and Farquhar, 1966; Shiino et al., 1972; Roubos and Van der Wal-Divendal., 1980). as in the case of proteinaceous secretory products stored as membrane-bound granules in variout tissues or organs (Pelletier et al., 1971; Douglas and Nagasawa, 1971; Douglas, 1974; Normann, 1976; Kurosumi and Inoue, 1980; Buma et al., 1984). Some granules 
were frequently observed to lie within the inpocketing of the cell membrane in prolactin cells (Ichikawa, 1959; Sano, 1962; Smith and Farquhar, 1966; Shiino et al., 1972; Roubos and Van der Wal-Divendal, 1980). Endocrine organs, in general, possess a rich capillary network, including the anterior pituitary. The contents of the granules enter in to the capillary space, after extrusion into the extracellular space by exocytosis and traversing through the parenchymal basal lamina (PBL), the pericapillary space, the endotherial basal lamina (EBL) and the endothelium. Among the process described above, it is considered that the PBL contacting with the cell membrane may present as an important structural element closely related to the mechanism of hormone released by exocytosis (Ichikawa, 1959; Farquhar, 1961; Pelletier et al., 1971). However, even in the ultrastructural investigations in regard to the hormone release in the pituitary gland, relatively little attention has been paid to the sites of secretory granule release (Farquhar, 1961; De Virgiliis et al., 1968; Pelletier et al., 1971). Since the pituitary and serem prolactin levels and regulated by the rates of synthesis and release in prolactin cells together with those of peripheral utilization and metabolism, the ultrastructural changes of prolactin cells should directly reflect the functional activities of prolactin secretion. In the present paper, using a morphometric method with the electron microscope, the correlation between the fluctuation in the frequency of the exocytotic figures of the secretory granules and the PBL during the estrous cycle was investigated in conjunction with the quantitative estimation of morphological changes in the cell-organelles.

\section{Materials and Methods}

Adult female mice of the IV-CS strain (exhibiting a 4 day estrous cycle) were housed under controlled conditions of temperature (about $24^{\circ} \mathrm{C}$ ) and illumination (light on 6:00-20:00). A commercial diet and water were available ad libitum. The estrous cycle was monitored by daily histological examinations of vaginal smears and mice exhibiting two consecutive 4 day estrous cycle were selected and used in this study. Twenty animals (five from each day of the estrous cycle) at about 90 days of age were sacrificed at 11:00 a.m. on the days of proestrus, estrus, metestrus and diestrus, and the pituitaries were rapidly exposed and covered with formardehyde-glutaldehyde fixative in $0.2 \mathrm{M}$ cacodylate buffer $\mathrm{pH} 7.4$ (Kalnovsky, 1965). To survey all the areas of the anterior pituitary, the pituitary gland was excised at the base of the skull and cut on the midsagittal plane. One half of each gland was diced into six pieces under a binocular siereoscope and the other was discarded (Sasaki et al., 1979). All the tissue blocks obtained were fixed in the same solution for further 2 hours and kept in cold $0.1 \mathrm{M}$ cacodylate buffer over night. They were postfixed in $1 \%$ osmium tetroxide (Plade, 1952) for 1 hour, dehydrated in a series of acetone solutions and embedded in Epon (Coulter, 1967). A single ultrathin section from each block was cut on a LKB 2008 ultramicrotome equipped with glass knives, mounted on a 250-mesh grid, stained with $5 \%$ uranyl acetate in alcohol and lead citrate solution. Sections were viewed with a Hitachi-11-DS electron microscope. Electron micrographs were taken from each meshwork of the grid at a magnification of $\times 2,300$ according to the method of Weibel and co-workers (1966). Prints were enlarged to a final magnification of $x 8,050$. The prolactin cells were easily identified from the characteristics of their secretory granules and cellorganelles (Sano, 1962; Barnes, 1962, 1963; Kurosumi, 1964). From all the electron micrographs obtained, about one hundred prolactin cells with a nucleus and the un- 
broken profile of the cell membrane per animal were selected at random. Morphometric observation was carried out under a binocular stereoscope.

As well known, there are a number of layers interposed between the capillary space and the parenchymal cells in the pituitary gland; endothelium, endotherial basal lamina (EBL), pericapillary space and parenchymal basal lamina (PBL) (Fig. 1). The cell perimeter was classified into two parts: one was in contact with the PBL and the other facing the intercellular space (ICS). The length of each part of the cell perimeter on all the given cells was measured with a photopattern analyzer (Digigrammer, Mutoh Ind. Co.). The numbers of exocytotic figures of secretory granules which were open to the PBL and ICS were respectively counted (Fig. 2).

The areas of each cell and cell-organelles including the nucleus, mitochondria, etc. were measured by a point counting method. A plastic sheet describing a square lattice with a $5 \mathrm{~mm}$ distance on the micrographs. The volumes of the nucleus, cytoplasm and cell-organelles were estimated from the total numbers of points falling on them.

To confirm 4 phases of the estrous cycle, overies taken from all the animals used were fixed in $10 \%$ formalin solution, dehydrated in a series of alcohol and embedded in paraffin. Sections were cut in the thickness of $6 \mu \mathrm{m}$ and stained with hematoxylin eosin.

An analysis of variance and Duncan's new multiple range test were used to evaluate differences between means of each group.

\section{Result}

The length of the cell perimeter of prolactin cells had a periodic change during the estrous cycle (Fig. 3). It was larger both in proestrus and estrus than in metest-

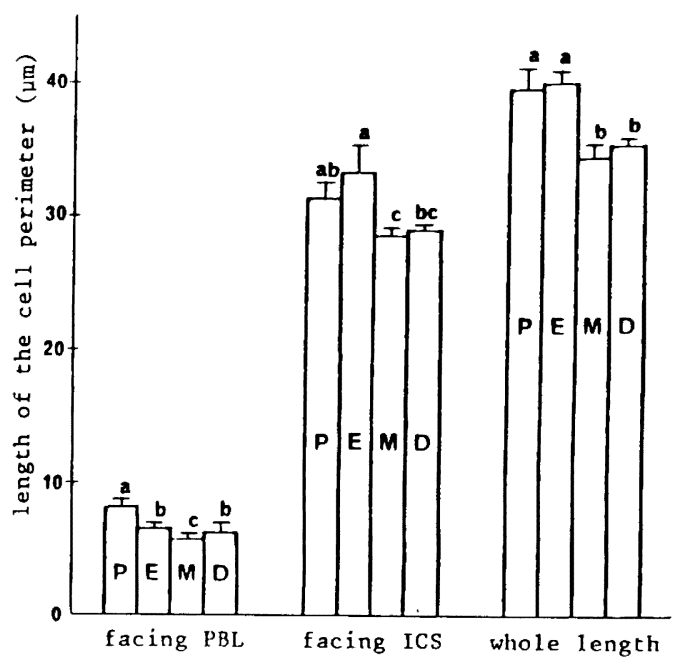

Fig. 3. The variations in the length of the cell perimeter of prolactin cells during the 4day estrous cycle. Columns show mean values with S.E. per cell. Significant differences indicated by different superscript letters in any one row differ at a level of $\mathrm{P}<0.05$ to comparison between each stage of the estrous cycle (Duncan's new multiple range test).

rus and diestrus $(\mathrm{P}<0.05)$. On each day of the estrous cycle, about $20 \%$ of the cell perimeter (proestrugs: $21 \%$, estrus: $17 \%$, diestrus: $18 \%$ ) was in contract with the PBL. The cell perimeter in contact with the PBL was definitely largest in proestrus among the other days of the estrous cycle $(P$ $<0.05)$. In regard to the cell perimeter facing the ICS, the length was longest in estrus and shortened in the order of proestrus, diestrus and meterstrus.

The number of exocytotic figures of secretory granules in prolactin cell during the estrous cycle had a clear periodic change as reported in Table 1. The number of exocytotic figures per cell was abundant on days of proestrus and estrus, decreased to the smallest level in metestrus and began to increase in diestrus. The numbers of those being open to the PBL and ICS were alike larger in proestrus and estrus than in metestrus and diestrus $(\mathrm{P}<0.05)$. 
Table 1. Number of exocy totic figures in prolactin cells during the estrous cycle (means \pm S.E., $n=5$ )

\begin{tabular}{|l|ccccccc|}
\hline & \multicolumn{3}{|c}{$\begin{array}{c}\text { number of exocytotic figures } \\
\text { of secretory granules per cell }\end{array}$} & & \multicolumn{3}{c|}{$\begin{array}{c}\text { number of exocytotic figures of } \\
\text { secretory granules per micrometer } \\
\text { of the cell perimeter }\end{array}$} \\
\cline { 2 - 5 } $\begin{array}{l}\text { stage of es- } \\
\text { trous cycle }\end{array}$ & open to PBL & open to ICS & total & open to PBL & open to ICS & total \\
\hline proestrus & $1.89 \pm 0.34^{\mathbf{a}}$ & $2.31 \pm 0.31^{\mathbf{a}}$ & $4.21 \pm 0.65^{\mathbf{a}}$ & $0.225 \pm 0.027^{\mathbf{a}}$ & $0.073 \pm 0.008^{\mathbf{a}}$ & $0.105 \pm 0.013^{\mathbf{a}}$ \\
estrus & $1.67 \pm 0.28^{\mathbf{a}}$ & $2.44 \pm 0.14^{\mathbf{a}}$ & $4.11 \pm 0.29^{\mathbf{a}}$ & $0.246 \pm 0.033^{\mathbf{a}}$ & $0.073 \pm 0.004^{\mathbf{a}}$ & $0.103 \pm 0.007^{\mathbf{a}}$ \\
metestrus & $0.23 \pm 0.02^{\mathbf{b}}$ & $0.33 \pm 0.06^{\mathbf{b}}$ & $0.56 \pm 0.07^{\mathbf{c}}$ & $0.041 \pm 0.004^{\mathbf{c}}$ & $0.012 \pm 0.002^{\mathbf{b}}$ & $0.016 \pm 0.002^{\mathbf{c}}$ \\
diestrus & $0.62 \pm 0.09^{\mathbf{b}}$ & $0.55 \pm 0.09^{\mathbf{b}}$ & $1.17 \pm 0.17^{\mathbf{b}}$ & $0.101 \pm 0.018^{\mathbf{b}}$ & $0.019 \pm 0.004^{\mathbf{b}}$ & $0.033 \pm 0.005 \mathbf{b}$ \\
\hline
\end{tabular}

Means with different superscript letters in any one column differ at a level of $\mathrm{P}<0.05$

(Duncan's new multiple range test).

During the estrous cycle, the number of exocytotic figures per micrometer of the cell perimeter expressed the same cyclic pattern as that per cell (Table 1). The exocytotic figures were frequently found in those parts of the cell in contact with the PBL during the estrous cycle, and the frequencies per micrometer of the cell perimeter were three- to five-fold over in the part facing the ICS $(\mathrm{P}<0.05)$ (Table 1).

During the estrous cycle, the cell-organelles in prolactin cells related to the synthesis and release of secretory granules showed a clear cyclic change (Fig. 4, 5,6). In proestrus and estrus, the prolactin cells were characterized by a well-developed Golgi apparatus in the supranuclear region, a number of mitochondria, secretory granules and RER and many exocytotic figures of secretory granule in the abundant cytoplasm. On the other hand, the size of cells was found to be smallest in metestrus, and their cytoplasm had most poorly developed cellorganelles and fewest secretory granules. In diestrus, the cell-organelles began to develop with the increase in the number of immature granules. The cytoplasm consequent. ly showed a little increase in size. The size of the nucleus was significantly larger both in proestrus and estrus than in metestrus and diestrus.

\section{Discussion}

The present study clearly indicates that the morphological changes in cell-organelles and frequencies of exocytotic release of secretory granules reflect a cyclic fluctuation of prolactin synthesis and release in prolactin cells of the mouse anterior pituitary during the estrous cycle. A rise in the volumes of secretory grannules and the cellorganelles began in diestrus, and reached a peak level in estrus. After reaching the peak the volumes rapidly decreased to a minimum level in metestrus. These results fairly agree with other works, using biochemical methods as bioassay or radioimmunoassay, by which the pituitary prolactin level was measured (Sar and Meites, 1967; Ieiri et al., 1972; Yanai and Nagasawa, 1974; Poole et al., 1980a, 1980b). Likewise, the release of secretory granules by exocytosis began 

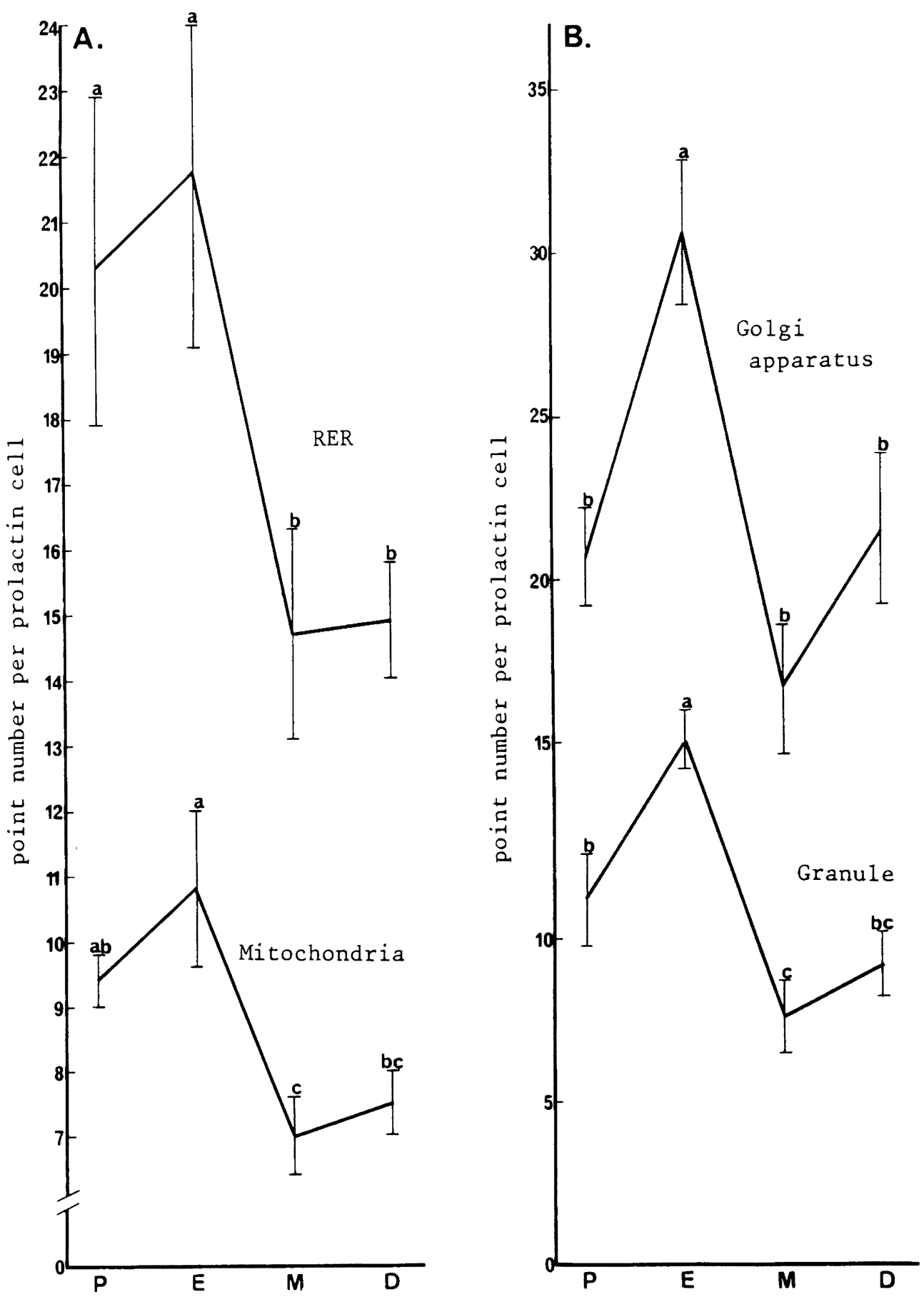

Fig. 5. A. The average volumes of RER and mitochondria per cell throughout the 4-day estrous cycle measured by the point counting method (point numbers per prolactin cell \pm S.E.).

B. The average volumes of Golgi apparatus and granule per cell as found throughout the estrous cycle (point numbers per cell \pm S.E.).

Significant differences indicated by different superscript letters in any one row differ at a level of $\mathrm{P}<0.05$ to comparison between each stage of the estrous cycle (Duncan's new multiple range test). 


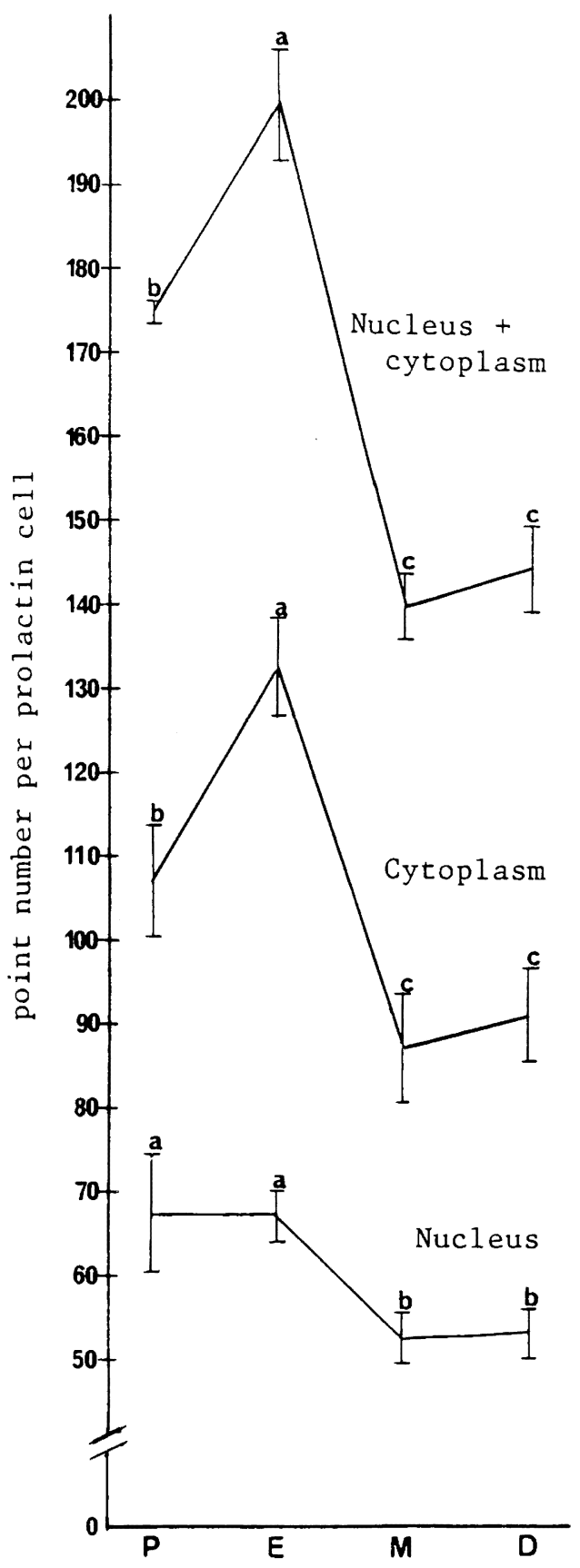

Fig. 6. The average volumes of cytoplasm and nucleus per cell, as found throughout the estrous cycle (point numbers per cell \pm S.E.). Significant differences indicated by different superscript letters in any one row differ at a level of $\mathrm{P}<0.05$ to comparison between each stage of the estrous cycle (Duncan's new multiple range test). to increase in diestrus and reached a peak level in proestrus, and this elevated level continued until estrus and dramatically fell down to a minimum in metestrus. Similarly the serum level of prolactin is found to be high in proestrus and/or estrus (Kwa and Verhofstad, 1967; Sar and Meites, 1967; Niswender et al., 1969; Amenomori et al., 1970; Gay et al., 1970; Neill, 1970, 1972a; Ieiri et al., 1971, 1972; Taya and Igarashi, 1973; Butcher et al., 1975; Wogensen and Warberg, 1980).

According to the biochemical analysis, the prolactin synthesis and release are promoted both by a rise in plasma estrogen' level which begins in diestrus and by a rise in plasma progesterone level which continues from metestrus until diestrus (Butcher et al., 1974; Smith et al., 1975), and thereafter a continuous increase in plasma estrogen level until proestrus (Brown-Grant et al., 1970; Butcher et al., 1974; Smith et al., 1975) may maintain the rise of prolactin synthesis and release. Furthermore, the elevated levels of the prolactin synthesis and release observed from proestrus to estrus and the rapid decrease in metestrus seem to be due to plasma progesterone level which dramatically increases in the afternoon of proestrus, reaches a peak level in the evening and then returns to the base level by the early morning of estrus (Butcher et al., 1974; Smith et al., 1975). These are suggested by many reports investigating the relations of estrogen and progesterone with the prolactin secretion (Nicoll and Meites, 1961; Ratner and Meites, 1964; Chen and Meites, 1970; Lu and Meites, 1971; Neill et al., 1971; Freeman et al., 1972; Mallampati and Johnson, 1972; Neill, 1972b; Ajica et al., 1972; Kalra et al., 1973; Caligaris et al., 1974; Yamamoto et al., 1975; Haug and Gautvic, 1976; Maurer and Gorski, 1977; Spona et al., 1979; Shull and Gorski, 1984).

Our morphometric investigations have 
shown a close relationship between the exocytotic release of secretory granules and the PBL: about $20 \%$ of the cell perimeter of prolactin cells are in contact with the PBL, regardless of the changes in the length of the cell perimeter, and the frequency of the granule release by exocytosis per micrometer of the cell perimeter in contact with the PBL showes 3-5 times higher values than that facing the ICS on any days of the estrous cycle. It was reported that the granule extrusion in acidophiles was observed in any parts of the cell membrane but more frequently in the part facing the PBL than in the part facing the ICS (Ichikawa, 1959), and it was also described both in acidophiles (growth hormone type) and gonadotrophs that the granules undergoing discharge were not often encountered between cells, but were commonly present along the perivascular connective tissue space (Farquhar, 1961) In corticotrophs, somatotrophs and thyrotrophs, Pelletier and co-workers (1971) claimed that the granule extrusion was found only in those parts of the cell that were in contact with the PBL. In our study, exocytotic figures were encountered in that part facing the ICS, only in small frequency, but the frequency in that contacting with the $\mathrm{PBL}$ was predominantly large. A number of mature granules were often observed to be stored within the vascular pole of the cell. Prolactin, synthesized by the ribosomes on RER and transfered through the RER cisternae into the Golgi apparatus, where it is condenced and packed into the secretory granules (Farquhar and Welling, 1957; Smith, 1963), is stored within the cell-body (Farquhar, 1971). When it is necessary, the contents of the granules are immediately discharged by exocytosis into the perivascular space via the PBL, so that there might be the mechanism by which the prolactin cells keep contact extensively with the PBL, and exocytosis frequently occurs at the cell surface adjacent to the PBL. The microtubules or the microfilaments which play the role of the cytoskeltone might lead the pathway for the intracellular translocation of the secretory granules (Lacy et al., 1968; Smith et al., 1970; Poisner and Bernstein, 1971; Williams and Wolff, 1972; Orci and Malaisse, 1972; Palade, 1975; Sasaki and Tashiro, 1976) up to the cellpole contacting with the PBL. If so, it can be considered that the exocytotic granulerelease may frequently occur in that part. It might be speculated that the cell membrane in the part contacting with the PBL has some physiochemical characteristics that the mechanism, as mentioned above, is attributed to the vascular elements like a organization of the blood capillary, PBL, EBL and so on or a component in the blood.

It is supposed from the fluctuation of the cell perimeter contacting with the PBL associated with the cyclic change in the secretory activity of prolactin cells that the length of $\mathrm{PBL}$ in contact with prolactin cells undergoes a periodic alteration. In diestrus, for low secretory activities, the cell perimeter in contact with the PBL was considerably long. In proestrus it reached maximal level and then returned to diestrus level in estrus, though secretory activity was still high at this time. From these results it could be deduced that, preceeding the rise in prolactin secretory activity (i.e., with a stimulating message), the PBL begins to spread and becomes widely attached to prolactin cells, though we cannot disregard the possibility that prolactin cells may deform to face widely to the PBL. Similarly, the PBL begins to reduce in its length prior to the falling in prolactin secretory activity (i.e., with a suppressing message). Consequently, prolactin cells could always contact with the PBL to almost the same proportion (about $20 \%$ ), in spite of the fluctuation of the cell perimeter during the estrous cycle. 


\section{Acknowledgement}

The authors wish to thank Professor T. Nobunaga, University of Tohoku for supply ing IV - CS mice, and Professor T. Wakabayashi for a pertinent criticism.

\section{References}

1) Ajica, K., Krulich, L., Fawcett, C.P. and McCann, S.M.: Effects of estrogen on plasma and pituitary gonadotropins and prolactin, and on hypothalamic releasing and inhibiting factors. Neuroendocrinology, $9: 304-315$, 1972

2) Amenomori, Y., Chen, C.L. and Meites, J.: Serum prolactin levels in rats during different productive states. Endocrinology, 86: 506-510, 1970.

3) Brown-Grant, K.D., Exley, D. and Naftolin, F.: Peripheral plasma oestradiol and luteinizing hormone concentrations during the oestrous cycle of the rat. J. Endocr., 48 295-296, 1970.

4) Buma, P., Roubos, E.W. and Buijis, R.M.: Ultrastructural demonstration of exocytosis of neural, neuroendocrine and endocrine secretions with an in vitro tannic acid (TARI-) method. Histochemistry, 80: 247-256, 1984.

5) Butcher, R.L., Collins, W.E. and Fugo, N.W.: Plasma concentration of $\mathrm{LH}, \mathrm{FSH}$, prolactin, progesterone and estradiol- $17 \dot{\beta}$ throughout the 4-day estrous cycle of the rat. Endocrinology, 94: 1704-1708, 1974.

6) Caligaris, L., Astrada, J.J. and Taleisnik, S.: Oestrogen and progesterone influence on the release of prolactin in ovariectomized rats. J. Endocr., 60: 205-215, 1974.

7) Chen, C.L. and Meites, J.: Effects of estrogen and progesterone on serum and pituitary prolactin levels in ovariectomized rats. Endocrinology, 86: 503-505, 1970.

8) Coulter, H.D.: Rapid and improved methods for embedding biological tissues in Epon 812 and Araldite 502. J. Ultrastruct. Res., 20: 346-355, 1967.

9) Douglas, W.W. and Nagasawa, J.: Membrane vesiculatin at sites of exocy tosis in the neurohypophysis, adenohypophysis and adrenal medulla: a device for membrane conservation. J. Physiol., 218: 94-95p. 1971.

10) Douglas, W.W.: Involvement of calcium in exocytosis and the exocytosis-vesiculation sequence. Biochem. Soc. Symp., 39: 1-28, 1974.

11) Farquhar, M.G. and Wellings, S.R.: Electron microscopic evidence suggesting secretory granule formation within the Golgi apparatus. J. Biophys. Biochem. Cytol,, 3: 319-324, 1957.

12) Farquhar, M.G.: Fine structure and function in capillaries of the anterior pituitary gland. Angiology, 12: 270-292, 1961.

13) Farquhar, M.G.: Processing of secretory products by cells of the anterior pituitary gland. Mem. Soc. Endocrinol., 19: 79-124, 1971.

14) Farquhar, M.G., Reid, J.A.J. and Daniell, L.W.: Intracellular transport and packaging of prolactin: a quantitative electron microscope autoradiographic study of mammotrophs dissociated from rat pituitaries. Endocrinology, 102: 296-311, 1978.

15) Freeman, M.E., Reichert, L.E.Jr. and Neill, J.D.: Regulation of the proestrus surge of prolactin secretion by gonadotropin and estrogens in the rat. Endocrinology, 90: 232-238, 1972.

16) Gay, V.I., Midgley, A.R.Jr. and Niswender, G.D: : Patterns of gonadotrophin secretion associated with ovulation. Federation Proc., 29: 1880-1887, 1970.

17) Hang, E. and Gautvic, K.M.: Effects of sex steroids on prolactin secreting rat pituitary cells in culture. Endocrinology, 99: 14821489, 1976.

18) Ichikawa, A.: Electron microscope study on secretion of the rat adenohypophysis. Acta. Anat. Nippon., 34: 460-482, 1959 (in Japanese).

19) Kalnovsky, M.J.: A formaldehyde-glutaraldehyde fixative of high osmolality for use electron microscopy. J.Cell Biol., 27: 270, 1965.

20) Kalra, P.S., Fawcett, C.P., Krulich, L. and McCann, S.M. : The effects of gonadal steroids on plasma gonadotropin in the rat. Endocrinology, 92: 1256-1268, 1973.

21) Kurosumi, K, : Electron microscopic analysis of the secretion mechanism. Int. Rev. Cytol., 11: $1-124,1964$.

22) Kurosumi, K. and Inoue, K.: Surface pits of typical gonadotrophs and castration cells of the rat anterior pituitary suggestive of exocytosis and micropinocytosis. Arch. histol. jap., 43: 373-382, 1980.

23) Kwa, H.G. and Verhofstad, F.: Prolactin levels in the plasma of female rats. J. Endocr., 39: 455-456, 1967. 
24) Lacy, P.E., Howell, S.L., Toung, D.A. and Fink, C.J.: New hypothesis of insulin secretion. Nature, 219: 1177-1179, 1968.

25) Lu, K.H. and Meites, J.: Direct inhibition by ergocornine of pituitary prolactin release. Endocrinology, $89: 229-233,1971$.

26) Mallampati, R.S. and Johnson, D.C.: Serum and pituitary luteinizing hormone, folliclestimulating hormone and prolactin levels in gonaectomized male, female rats treated with oestradiol benzoate. J. Endocr., 59 : 209$216,1973$.

27) Maurer, R.A. and Gorski, J.: Effects of estradiol-17 $\beta$ and pimozide on prolactin synthesis in male and female rats. Endocrinology, 101 : 76-84, 1977.

28) Nagasawa, J. : Exocytosis; the common release mechanism of secretory granules in glandular cells, neurons and paraneurons. Arch. histol. jap., 40 (suppl.): 31-47, 1977.

29) Neill, J.D.: Effect of "stress" on serum prolactin and luteinizing hormone levels during the estrous cycle of the rat. Endocrinology, 87: 1192-1197, 1970.

30) Neill, J.D., Freeman, M.E. and Tillson, S.A.: Control of the proestrus surge of prolactin and luteinizing hormone secretion by estrogens in the rats. Endocrinology, 89: 1448-1453, 1971.

31) Neill, J.D.: Comparison of plasma prolactin levels in cannulated and decapitated rats. Endocrinology, 90: 568-575, 1972a.

32) Neill, J.D. : Sexual differences in the hypothalamic regulation of prolactin secretion. Endocrinology, 90: 1154-1159, 1972 b.

33) Nicoll, C.S. and Meites, J.: Estrogen stimulation of prolactin production by rat adenohypophysis in vitro. Endocrinology, 70: 272-277, 1962.

34) Niswender, G.D., Chen, C.L., Midgley, A.R. Jr., Meites, J. and Ellis, S.: Radioimmunoassay for rat prolactin. Proc. Soc. Exp. Biol. \& Med., 130: 793-797, 1969.

35) Normann, T.C.: Neurosecretion by exocy tosis. Int. Rev. Cy tol., 46: 1-77, 1976.

36) Orci, L., Gabbay, K.H. and Malaisse, W.J.: Pancreatic beta-cell web: its possible role in insulin secretion. Science, 175: 1128-1130, 1972.

37) Palade, G.: Intracellular aspects of the process of protein synthesis. Science, 189: 347-358, 1975.

38) Palade, G.E.: A study of fixation for electron microscopy. J. Exp. Med., 95: 285-307, 1952.
39) Pelletier, G., Peillon, F. and Vilaporcile, E.: An ultrastructural study of site of granule extrusion in the anterior pituitary of the rat. Z. Zelforsch, 115: 501-507, 1971.

40) Poisner, A.M. and Berstein, J.: A possible role of microtubules in catecholamine release from the adrenal medulla: effect of colchicine vinca alkaloida and deuterium oxide. J. Pharmacol. Exp. Ther., 177: 102-108, 1971.

41) Poole, M.C., Mahesh, V.B. and Costoff, A.: Intracellular dynamics in pituitary mammotropes throughout the rat eatrous cycle. I. Morphometric methodology and hormonal correlations with cellular and nuclear volumes. Am. J. Anat., 158: 3-13, 1980a.

42) Poole, M.C., Mahesh, V.B. and Costoff, A.: Intracellular dynamics in pituitary mammotropes throughout the rat estrous cycle. II. Changes in synthetic and secretory organelles. Am. J. Anat., 158: 15-28, $1980 \mathrm{~b}$.

43) Ratner, A. and Meites, J.: Depletion of prolactin-inhibiting activity of rat hypothalamus by estradiol or suckling stimulus. Endocrinology, 75: 377-382, 1964.

44) Roubos, E.W. and Wal-Divendal, R.M. : Ultrastructural analysis of peptide-hormone release by exocytosis. Cell Tissue Res., 207: 267-275, 1980.

45) Sano, M. : Further studies on the theta cell of the mouse anterior pituitary as revealed by electron microscopy, with special reference to the mode of secretion. J. Cell Biol., 75: 85-97, 1962.

46) Sar, M. and Meites, J.: Changes in pituitary prolactin release and hypothalamic PIF content during the estrous cycle of rats. Proc. Soc. Exp. Biol. \& Med., 125: 1018-1021, 1967.

47) Sasaki, F.: Quantitative studies by electron microscopy on the sex-difference and the change during the oestrous cycle in the mouse anterior pituitary. Arch. histol. jap., 37: 41$57,1974$.

48) Sasaki, F., Iwama, Y. and Sano, M.: Straindifference in prolactin cells of mouse anterior pituitary between high and low mammary tumor strains by stereological morphometry with an electron microscope. Okajimas Folia Anat. Jpn., 55: 341-350, 1979.

49) Sasaki, S. and Tashiro, Y.: Studies on the posterior silk gland of the silkworm Bomyx Mori. VI. Distribution of microtubules in the posterior silk gland cells. J. Cell Biol., 71: 565-574, 1976.

50) Schmitt, F.O.: Fibrous proteins-neuronal organelles. Proc. Natl. Acad. Sci. U. S.A., 
60: 1092-1101, 1968 .

51) Shiino, M., Williams, G. and Rennels, E.G.: Ultrastructural observation of pituitary release of prolactin in the rat by suckling stimulus. Endocrinology, 90: 176-187, 1972.

52) Shull, L.D. and Gorski, J.: Estrogen stimulates prolactin gene transcription by a mechanism independent of pituitary protein synthesis. Endocrinology, 114: 1550-1557, 1984

53) Smith, D.S., Järlfors, U. and Beránek, R.: The organization of synaptic axoplasm in the lamprey (Petromyzon marinus) central nervous system. J. Cell Biol., 46: 199-219, 1970.

54) Smith, R.E. and Farquhar, M.G.: Lysosome function in the regulation of the secretory process in cells of the anterior pituitary gland. J. Cell Biol., 31 : 319-347, 1966.

55) Smith, M.S., Freeman, M.E. and Neill, J.D.: The control of progesterone secretion during the estrous cycle and early pseudopregnancy in the rat: prolactin, gonadotropin and steroid levels associated with rescue of the corpus luteum of pseudopregnancy. Endocrionlogy, 96: 219-226, 1975.

56) Spona, J., Leibl, H. and Bieglmayer, C.: Nuclear translocation of estrogen-receptor complex and stimulation of RNA synthesis by estrogens of different biological potencies in the female rat pituitary. Biochim. Biophys. Acta, 607: 189-200, 1980.

57) Taya, K. and Igarashi, M.: Changes in FSH, $\mathrm{LH}$ and Prolactin secretion during estrous cycle in rats. Endocrinol. japon., 20: 199205, 1973.

58) Virgiliis, G.D., Meldolesi, J. and Clementi, F.: Ultrastructure of growth hormone-producing cells of rat pituitary after injection of hypothalamic extract. Endocrinology, 83: 1278$1284,1968$.

59) Weibel, E.R., Kistler, G.S. and Scherle, W.F.: Practical stereological methods for morphometric cytology. J. Cell Biol., 30: 23-38, 1966.

60) Williams, J.A. and Wolff, J. Colchicine-binding protein and the secretion of thyroid hormone. J. Cell Biol., 54: 157-165, 1972.

61) Wogensen, L. and Warberg, J. : Cyclic and diurnal alterations in the response of luteinizing hormone and prolactin to prostaglandin $\mathrm{E}_{2}$ during the rat oestrous cycle. Acta Endocrinol., 106: 30-37, 1984.

62) Yamamoto, K. Kasai, K. and Ieiri, T.: Control of pituitary functions of synthesis and release by gonadal steroids in female and male rats. Jap. J. Physiol., 25: 645-658, 1975.

\section{Explanation of Figures}

$\mathrm{CAP}:$ Capillary lumen
$\mathrm{Cmb}:$ Cell membrane in contact with the perenchymal basal

$\mathrm{Cmi} \quad$ lamina
$\mathrm{D}:$ Cell membrane facing the intercellular space
$\mathrm{E} \quad:$ Diestrus
$\mathrm{EBL}:$ Estrus
$\mathrm{End} \quad:$ Capillary endothelium
$\mathrm{G} \quad:$ Golgi apparatus
$\mathrm{M} \quad$. Metestrus

$\mathrm{N}$ : Nucleus

Nuc : Nucleolus

$\mathrm{P} \quad$ : Proestrus

PBL : Parenchymal basal lamina

PCS : Pericapillary space

PL : Prolactin cell

KBC: Erythrocyte

RER: Rough endoplasmic reticulum 


\section{PLATES}




\section{Explanation of Figures}

\section{Plate I}

Fig. 1. A semidiagramatic representation of a prolactin cells of the anterior pituitary gland. The cell membrane of the prolactin cell is partly in contact with PBL. Some exocy totic figures (arrows) are seen facing PBL or ICS. 







\section{Plate II}

Fig. 2. Exocy totic granule extrusion (arrow) is open to PBL (A) $\mathrm{Ci}_{i}$ open to ICS (B). $\times 12,000$ 

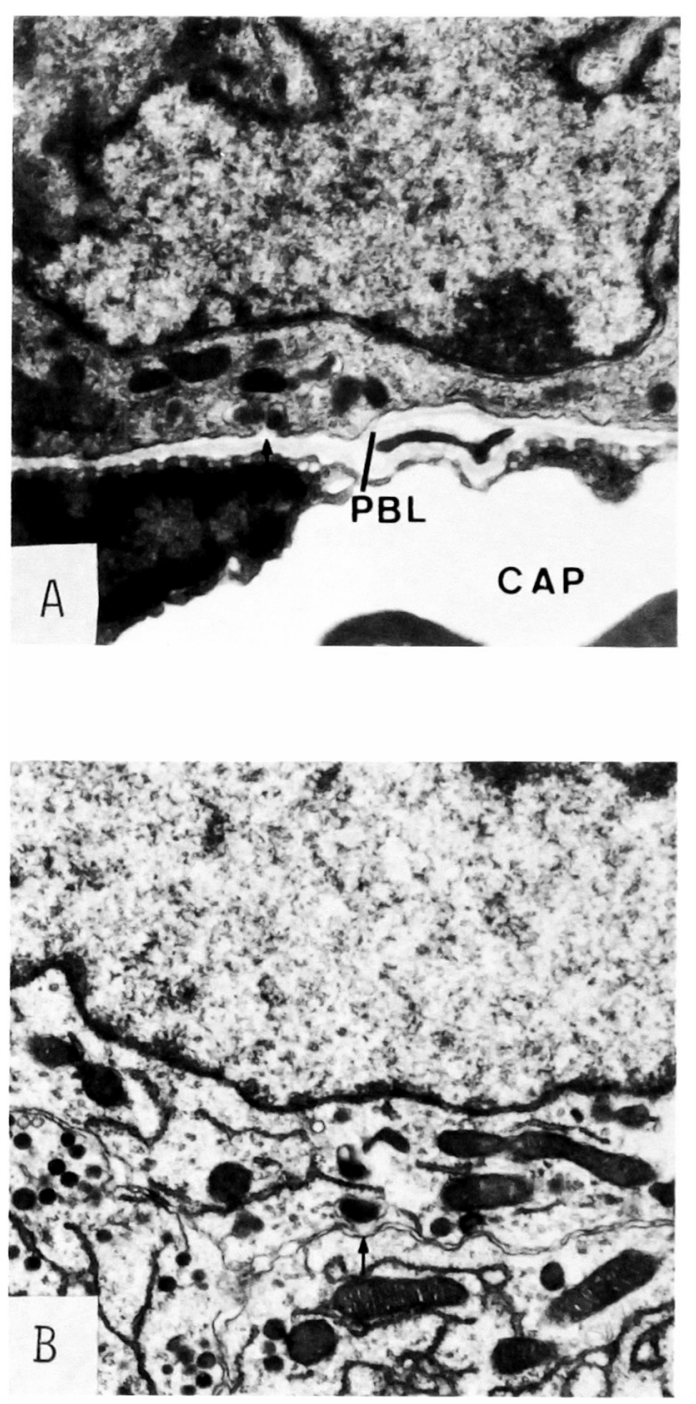


\section{Plate III}

Fig. 4. Representative prolactin cell on each stage of the estrous cycle. Proestrus (A) : many mature granules, several exocy totic figures (arrows) are seen at a cell-pole and a considerably developed Golgi apparatus is observed in supranuclear region. Estrus (B) : a r.umber of mature granules, several exocytotic figures (arrows) and a highly developed Golgi apparatus are seen. Metestrues (C) : few mature or immature granules and one exocytotic figure are seen and cell-organelles are poorly developed. Diestrus (D) : many immature granules, a fairly developed Golgi apparatus and some exocytotic figures (arrows) are seen. $\times 5,500$ 
Exocytosis in Prolactin Cells during the Estrous Cycle 311

Plate III
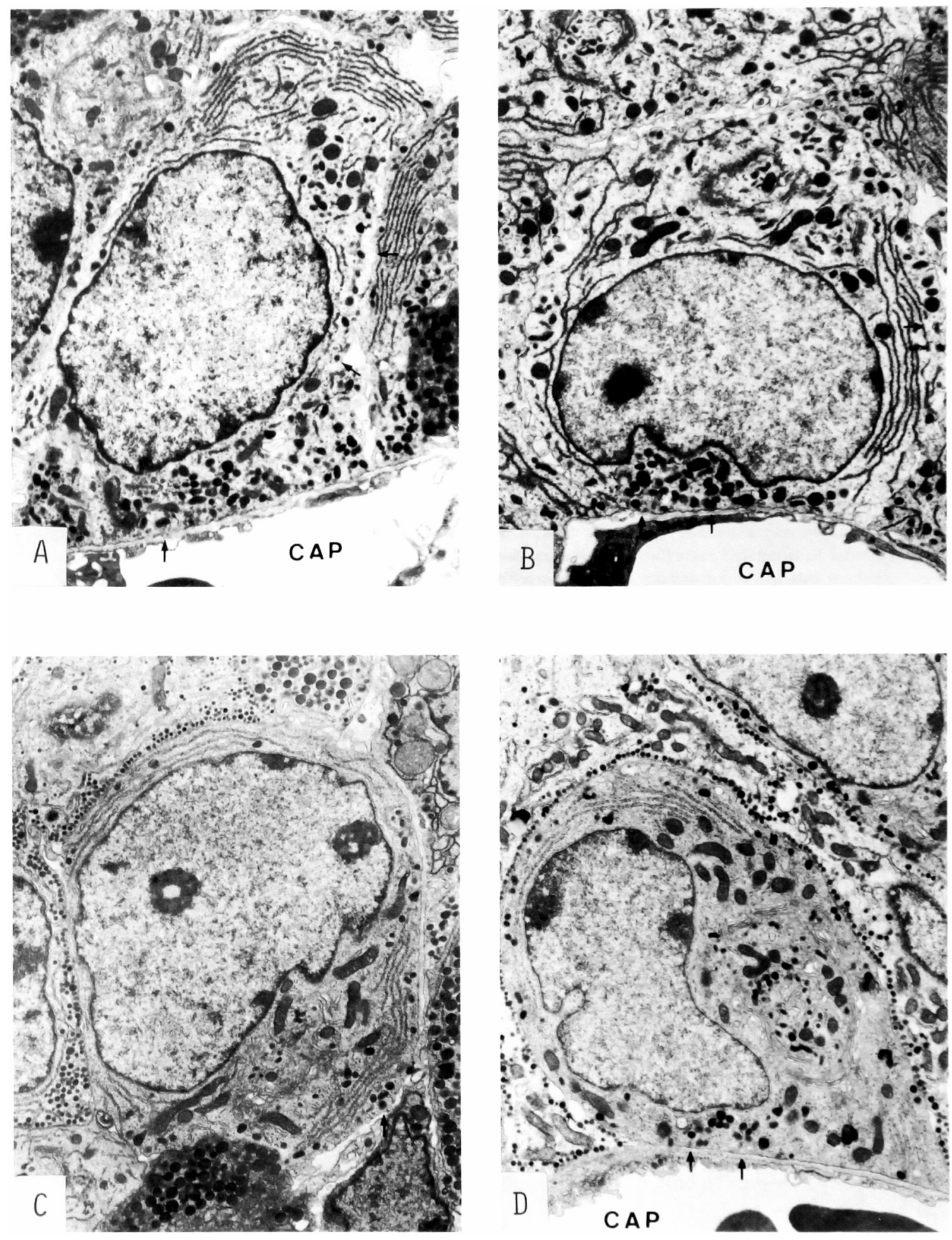